DOI: $10.15393 / j 9$. art.2013.378

\author{
Рита Осиповна Мазель \\ учитель русского языка и литературы, \\ исследователь творчества Ф. М. Достоевского, \\ Лицей №1501 г. Москвы \\ (Москва, Российская Федераичи) \\ levinanadya@mail.ru.
}

\title{
СЦЕНЫ СЧАСТЬЯ В РОМАНАХ ДОСТОЕВСКОГО
}

Аннотация: В предлагаемой статье Достоевский предстает перед читателем как поэт счастья. Пережив уникальный опыт страданий, он постиг иное измерение жизни. Со страстью первооткрывателя он утверждает благодать живой жизни. «Жизнь - дар, жизнь - счастье, каждая минута может быть веком счастья», - вот главное в его великих романах.

Люди на земле не одиноки, а связаны незримыми нитями: один человек не может состояться, одно сердце, одно сознание как магнитом притягивает к себе другое, как бы утверждая: Ты еси... Величайшее чудо на земле - Христос, Его любовь и Его жертва. Невозможно знать, что есть Христос, и не радоваться.

Достоевский открывает один из главных законов жизни: любовью принося в жертву свое я другому, человек исполняет закон стремления к идеалу и чувствует райское наслаждение.

В статье дан анализ некоторых сцен счастья в романах Достоевского: восторг Аркадия и его сестры Лизы перед жертвой их отца Версилова; Алеша и Грушенька, вместо падения и греха спасающие друг друга; сон Алеши о чуде, сотворенном Иисусом в Кане Галилейской; сон Ставрогина о золотом веке счастливого человечества... В трагическом романе «Бесы» перед читателем предстает картина любви - взаимной, жертвенной, полнокровной, счастливой. Ничего подобного нет, пожалуй, во всей мировой литературе.

В героях Достоевского особенно ощущается сопричастность иному, высшему миру, который проникает в каждую клеточку их жизни. Его создания все осияны светом миров иных. У Достоевского по определению не может быть мрака, отчаяния, безысходности, потому что и в бесовском аду остались праведники, светоносные (по слову Н. Бердяева), способные любить и жертвовать собой, а значит, свет еще светит во тьме, и тьма бесовства не объяла его.

Ключевые слова: Достоевский, радость, счастье, Христос, сцены, поэтика романа

\footnotetext{
7 остоевский — поэт счастья, исступленно любящий живую жизнь. «Жизнь - дар, жизнь - счастье, каждая минута могла быть веком счастья», - пишет он брату через несколько часов после эшафота.
} 
...Как оглянусь на прошлое и подумаю, сколько времени пропало в заблуждениях, в ошибках, в праздности... сколько раз я грешил против сердца моего и духа, так кровью обливается сердце мое... (XXVII, кн. 1, 163) ${ }^{1}$.

Это слова человека, только что видевшего перед собой смерть. В письме слышится потрясенность души и радостная взволнованность возвращения к жизни. Испытания и страдания ничто по сравнению с высшей ценностью жизни. Не раз оказывавшийся пред черной бездной небытия, Достоевский напряженно чувствует божественную тайну бытия, благодать жизни $[3,117]$.

В романе «Идиот» есть такое загадочное место. Умирающий Ипполит спрашивает Мышкина, как ему всего лучше умереть: «...как можно добродетельнее...». Мышкин отвечает:

Пройдите мимо нас и простите нам наше счастье (VIII, 433).

Ипполит лишается счастья жизни. В каждом романе великого писателя говорится об этом счастье. Раскольников готов жить хоть на аршине пространства, только бы жить. Кириллов с упоением вспоминает впечатления детства осенний лист на земле, чуть подгнивший с краев. Мученик своего неверия, Иван Карамазов признается, как дороги ему клейкие весенние листочки, голубое небо, дорог иной человек неизвестно за что... Эту силу жизни он называет земляной, карамазовской, способной все вытерпеть...

Праведники у Достоевского - Зосима, его брат Маркел, Макар Долгорукий - счастливы и прославляют Бога и живую жизнь. Бог - это радость, веселье. О докторе Александре Семеновиче в романе «Подросток» Макар говорит: «Нет, ты не безбожник, ты человек веселый». В то же время персонажи, которые выключены из круга живой жизни - Лужин, Тоцкий, Миусов, Ракитин, или обделенные благодатью Свидригайлов и Смердяков - никогда не переживают веселья и счастья.

Можно сказать, что ценность человека у Достоевского определяется его способностью быть счастливым. В романе «Идиот» князь Мышкин часто бывает счастлив. Он проникает в другие души, отыскивая в них доброе, собственное по- 
ложение его не интересует, в нем нет того, что много позже о. Александр Шмеман в Дневниках назвал яйностью².

С какой радостью Мышкин рассказывает Рогожину о случайно замеченной им простой бабе, которая радостно улыбается своему младенцу в ответ на его первую улыбку, так объясняя случайному прохожему, князю, свою радость:

Вот так же точно бывает и у Бога радость, когда он с неба завидит, что грешник перед Ним от всего своего сердца на молитву становится...

И тот радуется, что вот - простая баба:

... такую важную мысль выразила, где все понятие о Боге как о нашем родном отце и о радости Бога на человека, как отца на свое родное дитя (VIII, 183-184).

Перед пошлыми светскими людьми, считающими его чудаком и больным, князь Мышкин открывает свою душу:

О, что такое мое горе и моя беда, если я в силах быть счастливым? Знаете, я не понимаю, как можно проходить мимо дерева и не быть счастливым, что видишь его? Говорить с человеком и не быть счастливым, что любишь его?.. А сколько вещей на каждом шагу таких прекрасных, которые даже самый потерявшийся человек находит прекрасными? Посмотрите на ребенка, посмотрите на Божию зарю, посмотрите на травку, как она растет, посмотрите в глаза, которые на вас смотрят и вас любят... (VIII, 459).

Отрицать все это - значит грешить против Святого Духа, который дышит в мире, где хочет...

Словами Ипполита в романе «Идиот» писатель проводит такую интереснейшую мысль:

Бросая ваше семя... ваше доброе дело... вы отдаете часть вашей личности и принимаете в себя часть другой; вы взаимно приобщаетесь один к другому... С другой стороны, все ваши мысли, все брошенные вами семена... воплотятся и вырастут. Получивший от вас передаст другому... Вы непременно станете смотреть наконец на ваше дело как на науку (VIII, 336).

Это и есть главное содержание романов Достоевского. Люди не одиноки и не брошены в пустом пространстве. Человеческие души связаны таинственными нитями с Созда- 
телем и друг с другом. Одно сознание, как магнитное поле, притягивает другое. Ухтомский назвал это «доминантой на лицо другого человека» [5].

Отношение героя к себе самому неразрывно «связано с отношением его к другому или с отношением другого к нему» [2, 354].

Известно, что сияющим идеалом человека на земле для Достоевского был Христос. В письме к Н. Д. Фонвизиной от 20 февраля 1854 г. он утверждает свой символ веры:

...верить, что нет ничего прекраснее, глубже, симпатичнее, разумнее, мужественнее и совершеннее Христа...(XXVIII, кн. 1, 176).

В каждом человеке писатель открывает Христа. Поэтому в отношениях человека к другому человеку очень важна и необходима вера:

Если я несовершенен, гадок и зол, то я знаю, что есть другой, идеал мой, который прекрасен, свят и блажен (XI, 189).

Отсюда это трепетное, исступленное отношение между людьми у Достоевского. Как говорит Шатов Ставрогину:

Мы два существа и сошлись в беспредельности... в последний раз в мире (X, 195).

И еще очень важно. Аристотель в «Этике» (Письма к Никомаху) дал такое определение счастья: «Счастье - это некая деятельность души в полноте добродетели» [1].

Достоевский в известной записи «Маша лежит на столе...» (в апреле 1864 г. в связи со смертью жены) находит для определения счастья новые грани.

Возлюбить человека, как самого себя, по заповеди Христовой, невозможно. Закон личности на земле связывает... Когда человек не исполнил закона стремления к идеалу, то есть не приносил любовью в жертву своего я людям или другому существу (я и Маша), он чувствует страдание и назвал это состояние грехом. Итак, человек беспрерывно должен чувствовать страдание, которое уравновешивается райским наслаждением исполнения закона, то есть жертвой... (XX, 172-175).

И сколько же здесь у Достоевского открытий. 
После убийства Раскольников, окаменевший, впавший в жуткий мрак, неожиданно на улице став свидетелем того, как лошадь сбила Мармеладова, тащит его на себе, окровавленного, а потом с радостью говорит полицейскому Никодиму Фомичу: «Я весь в крови» (то есть на нем не только кровь убитых им старухи и Лизаветы, но и кровь спасаемого им Мармеладова). Он со счастьем обнимает Поленьку, на какое-то время возрождаясь от приятия и молитвы ребенка. Счастье - это остро ощущаемое созвучие с другой душой.

Убив, Раскольников внутренне отрезал себя от родных, близка ему только опозоренная и презираемая Соня. В каморке Раскольникова буквально убитая мать протискивается к выходу, второпях как-то не попрощавшись с Соней. Дуня, только что резко спорившая с братом, выходя вслед за матерью, «откланялась Соне внимательным, вежливым и полным поклоном». Родион Романович счастлив - Дуня сразу стала ему близка.

Дуня, прощай, — кричит он ей уже в сенях, — дай руку-то... Да ведь я уже подавала, забыл, - отвечала Дуня, ласково и неловко оборачиваясь к нему. - Ну что ж, еще дай! - и он крепко стиснул ее пальчики. Дунечка улыбнулась, закраснелась, поскорее вырвала свою руку и ушла вслед за матерью, тоже почему-то вся счастливая (VI, 184).

Спокойно и естественно перешагнув через общепринятые предрассудки, она исполнила какой-то важный закон жизни и почувствовала, как стала близка и дорога брату.

В «Бесах», самом трагическом романе, есть страницы захватывающего счастья. Это счастье порой согласного звучания голосов епископа Тихона и преступника Ставрогина. Это когда великие слова Апокалипсиса на какое-то время растопили застывшую душу Ставрогина, и он впервые в жизни говорит Тихону: «Я вас очень люблю» (XI, 11). А сон Ставрогина о картине Лоррена «Асис и Галатея», названной писателем «Золотой век», сон, когда, как говорит Достоевский, «исчезают пространство и время и действие останавливается на точках, о которых грезит сердце». Эта картина снится Ставрогину как какая-то быль. 
Уголок греческого архипелага три тысячи лет назад - ласковые волны, острова и скалы, цветущее прибрежье, волшебная панорама вдали, заходящее зовущее солнце... Здесь был земной рай человечества, боги сходили с небес и роднились с людьми. Тут жили прекрасные люди... О как я рад был, что у меня трепещет сердце и что я их наконец люблю!.. О чудный сон, высокое заблуждение... Мечта самая невероятная из всех, какие были, но которой все человечество всю свою жизнь отдавало все свои силы, для которой всем жертвовало... И все это ощущение я как будто прожил в этом сне, когда проснулся и раскрыл глаза, в первый раз в жизни буквально омоченные слезами. Ощущение счастья, еще мне неизвестного, прошло сквозь все сердце мое даже до боли... (XI, 21-29).

Так вот о чем грезило сердце, неведомо для него самого, преступника Ставрогина, и что прорвалось в его сне - о чистой красоте и любви счастливого единого человечества. И как чаще всего у героев Достоевского - счастье непременно вселенское, чтобы «все и вся». Вот какие глубины могут быть в самом падшем человеке. Правда, потом маленький красный паучок на листке герани напомнит о страшном преступлении и вызовет муки совести, самоугрызение и гибель.

В романе «Подросток» есть замечательная сцена счастья, любви, восторга. Подросток Аркадий, заброшенный, обиженный, член «случайного семейства», и его сестра Лиза, которую он совсем мало знает, идут по залитой солнцем петербургской улице. Аркадий счастлив. Он только что узнал, что отец его, Версилов, впавший с семьей в нищету, отказался от своих прав на наследство. Вот это самое главное: нравственный подвиг, жертва любимого человека. «Ибо сей человек был мертв и ожил, пропадал и нашелся», - объясняет Аркадий свое состояние Лизе словами евангельской притчи о блудном сыне: ведь здесь не подходят обычные житейские слова. Аркадий захлебывается от радостного волнения:

- Я тебя ужасно люблю, Лиза! Пусть приходит, когда надо, смерть, а пока жить, жить! О той несчастной (самоубийце Оле) пожалеем, а жизнь все-таки благословим, так ли?.. Лиза, ты ведь знаешь, что Версилов отказался от наследства?

- Как не знать? Мы с мамой уже целовались. 
- Ты не знаешь души моей, Лиза, ты не знаешь, что значит для меня человек этот...

Вот что значит - «одного безумия люди»: их ввергают в нищету, а они целуются, как при большом празднике. Вся сцена залита солнцем и светом. И звучат слова Лизы (почти такие же, что сказал Алеша, прощаясь с мальчиками в эпилоге «Братьев Карамазовых»):

...если когда-нибудь мы обвиним друг друга, если будем в чем недовольны, если сделаемся сами злы, дурны, если даже забудем все это, - то не забудем никогда этого дня и вот этого самого часа (XIII, 161).

Сравним с речью Алеши при прощании с мальчиками у Илюшина камня - о том, как соединяют людей прощение и любовь:

...не забывайте никогда, как нам было здесь хорошо, всем сообща, соединенным таким хорошим и добрым чувством, которое и нас сделало на это время любви нашей к бедному мальчику, может быть, лучшими, чем мы есть в самом деле... Ах, деточки, ах, милые друзья мои, не бойтесь жизни! Как хороша жизнь, когда что-нибудь сделаешь хорошее и правдивое! (XV, 195-196).

В эпизоде встречи Алеши и Грушеньки тоже все неожиданно. Грушенька давно мечтала его «проглотить», уязвленная его целомудрием, где-то в глубине души обиженная на всех мужчин. Алеша, приведенный к ней Ракитиным, предвкушающим его падение, после смерти старца Зосимы и последующих за этим бесчинств, находится в таком состоянии, что чем хуже, тем лучше. Но вместо того чтобы впасть в грех, они спасают друг друга. Каждый из них открывает в другом «сокровенного сердца человека».

Узнав о смерти старца Зосимы, Грушенька испуганно вскакивает с колен Алеши, куда она уже уселась, и истово крестится.

Алеша длинно и с удивлением поглядел на нее и в лице его как будто что засветилось (XIV, 318).

Добро и великодушие одного человека тут же отзывается в другом. 
...Посмотри сюда на нее, - указывает Алеша Ракитину на Грушеньку, - видел, как она меня пощадила? Я шел сюда злую душу найти - так влекло меня самого к тому, потому что я был подл и зол, а нашел сестру искреннюю, нашел сокровище - душу любящую... Она сейчас пощадила меня. Аграфена Александровна, я про тебя говорю. Ты мою душу сейчас восстановила (XIV, 318).

Грушенька потрясена. В эту минуту она всех простила и у всех просит прощения. Ракитин при этом злобно издевается, что Алеша

...обратил грешницу. Блудницу на путь истины обратил. Семь бесов изгнал... (XIV, 324).

Для человека толпы непостижим этот чудесный порыв души к душе, вызванный великодушием, - главное в мире Достоевского.

О райском наслаждении от неожиданного собственного благородства рассказывает Алеше Митя Карамазов, потрясенный самопожертвованием Катерины Ивановны ради отца. И вместо того чтобы потешиться над нею «по-поросячьи», вручает ей с поклоном пять тысяч. Затем достал шпагу и хотел заколоть себя - от восторга, видимо, как-то раздавленный впечатлениями этого двойного - ее и своего великодушия...

В главе «Братья знакомятся» восторг и счастье переживают Иван и Алеша, два «русских мальчика», решающих в скотопригоньевском трактире «Столичный город» главные вопросы бытия. Они очень молоды, им радостно узнавать друг друга. «Одного из русских мальчиков я очень люблю», — весело признается Иван Алеше. И оба в восторге от признания Алеши философу Ивану, что он, Иван, при своей солидности и значительности, такой же «желторотый молоденький мальчик...»

Пройдет немного времени и будет найден убитым Федор Павлович Карамазов. Иван, измученный сомнениями, убил ли отца Смердяков, бывший под его влиянием, в их последнем - третьем разговоре наконец прорывается к правде. Он решает, что завтра пойдет в суд вместе со Смердяковым и объявит, что он тоже убийца: ведь в помыслах он хотел 
смерти отца, Смердяков это знал, а с совестью своей Иван никогда не вступает в сделку.

Какая-то словно радость сошла теперь в его душу. Он почувствовал в себе какую-то бесконечную твердость: конец колебаниям его, столь ужасно его мучившим все последнее время! Решение было взято и уже не изменится, - со счастьем подумал он. В это мгновение он вдруг на что-то споткнулся и чуть не упал. Остановясь, он различил в ногах своих поверженного им мужичонку, все так же лежавшего на том же самом месте, без чувств и без движения. Метель уже засыпала ему почти все лицо. Иван вдруг схватил его и потащил на себе... (XV, 68-69).

И вот он возится с мужичонкой, как милосердный самарянин, стучится в первый встречный дом, дает хозяину деньги, чтобы тот позаботился о больном, и с наслаждением отмечает, что это оттого, что решение его твердо принято.

Жертвовать собою и всем для правды - вот национальная черта поколения (XI, 303).

Иван радостно предвкушает свое публичное покаяние. И хоть эта радость длилась недолго, но как сказал в «Бесах» епископ Тихон, ни одна мысль, ни одна полумысль не пропадут даром для Господа (XI, 29).

Самая высшая сцена счастья - это сон Алеши о Кане Галилейской.

Ax, это чудо, ах, это милое чудо! Не горе, а радость людскую посетил Христос, в первый раз сотворяя чудо, радости людской помог... (XIV, 326).

Особенно потрясло Алешу, что это чудо Христос сотворил по просьбе матери своей ради бедных, очень бедных людей, претворив для них воду в вино, ибо на свадьбе «вина у них не достало...». И во сне этом перед ним радостный, дорогой старец указывает на

...солнце наше... Не бойся Его. Страшен величием перед нами, ужасен высотою своею, но милостив бесконечно...

Что-то горело в сердце Алеши, что-то наполнило его вдруг до боли, слезы восторга рвались из души его... 
И дальше неотделима от чудного сна сцена счастья и благодарения:

Над ним широко, необозримо опрокинулся небесный купол, полный тихих сияющих звезд... Тишина земная как бы сливалась с небесною, тайна земная соприкасалась со звездною...(XIV, 328).

Алеша падает на землю и целует ее, всю, плача, обливая слезами восторга.

Простить хотелось ему всех и за все и просить прощения, о! не себе, а за всех, за все и за вся... Пал он на землю слабым юношей, а встал твердым на всю жизнь бойцом... "Кто-то посетил мою душу в тот час", - говорил он потом с твердою верой в слова свои... (XIV, 327-328).

Веруя в бессмертие души, Достоевский в то же время жаждал вселенского счастья здесь, на земле. В замечательной утопии «Сон смешного человека» сон о райской жизни на далекой неведомой звезде убедил героя в истине:

Я видел истину, я видел и знаю, что люди могут быть прекрасны и счастливы, не потеряв способности жить на земле (XXV, 118).

Он знает, что рай на земле неосуществим. Но он все-таки будет проповедовать. Конечно, жизнь могла бы мгновенно превратиться в рай.

Так это просто: в один бы день, в один бы час все бы сразу устроилось! Главное, люби других, как себя, вот что главное, и это все, больше ничего не надо: тотчас найдешь, как устроиться (XXV, 119).

Принцип реализма Достоевского категоричен:

Идеал ведь тоже действительность, такая же законная, как и текущая действительность (XXI, 75).

Очень близка к «Сну смешного человека» миниатюра «Золотой век в кармане» (Дневник писателя. 1876 год. Январь), где перед нами картина бездарного, пошлого светского бала.

И пришла мне в голову одна фантастическая и донельзя дикая мысль: «Ну что, - подумал я, - если б все эти милые и почтенные гости захотели, хоть на миг один, стать искренними и простодушными, - во что бы обратилась тогда вдруг эта душная зала?.. Что, если 6 каждый из них вдруг узнал, сколько заключено в нем пря- 
модушия, честности, самой искренней сердечной веселости, чистоты, великодушных чувств, добрых желаний, ума, - куда ума! остроумия самого тонкого, самого сообщительного, и это в каждом, решительно в каждом из них!» Да, господа... И эта мощь есть в каждом из вас, но до того глубоко запрятанная, что давно уже стала казаться невероятною (XXII, 12-13).

Достоевский, со своей проповедью добра, жаждет чуда и надеется на чудо: а вдруг люди услышат, опомнятся и преобразятся?..

Самое главное счастье для человека - в любви. Глубоко постигший тайну Достоевского Бердяев остался глух к любви в его романах. Это отметил еще Померанц $[4,156]$. Именно в трагических «Бесах» перед нами картина любви, пылкой, трепетной, всепрощающей, жертвенной. Речь идет о любви Шатова к жене. Подобного описания любви, думается, не было еще в литературе. Удивительно, что никто этого не заметил. Правда, митрополит Антоний (Храповицкий) в статье «Словарь Достоевского», написанной еще в 20-е годы, посвятил этому несколько строк. «Это чудная картина евангельского всепрощения, с одной стороны, и смягчения ожесточенного сердца - с другой, возвышает перо нашего писателя до кисти Рафаэля и Нестерова $[6,65]$.

К Шатову неожиданно приехала бросившая его в Швейцарии еще три года назад жена, «прожив с ним до этого всего две с половиной недели», «притащилась» (слово митрополита Антония), нищая и в безысходности, и мучается, раньше срока рожая ставрогинского ребенка.

Шатов ни о чем не догадывается.

Робко, с каким-то небывалым сиянием в лице он ее слушал. Этот сильный и шершавый человек... вдруг весь смягчился и просветлел... три года разлуки не вытеснили из сердца его ничего... но вот это единственное существо, две недели его любившее (он всегда этому верил), - существо, которое он всегда считал неизмеримо выше себя, которому он совершенно все, все мог простить... Эта женщина, эта Мария Шатова вдруг опять в его доме, опять перед ним... В этом событии заключалось для него столько чего-то страшного и вместе с тем столько счастья... Но когда она поглядела на него этим измученным взглядом, вдруг он понял, 
что это столь любимое существо страдает, может быть обижено, сердце его замерло (X, 435).

Сломя голову Шатов бросается к Кириллову, с которым они год не разговаривали. Кириллов с радостной готовностью тут же отдает ему все:

Бери, друг, все бери... Берите все, берите сахар, весь хлеб. Чайник еще горячий, самый горячий. Есть телятина, денег рубль... (X, 436).

Их вражда, равнодушие растоплены. Кириллов счастлив, что Шатов способен к такой великой любви, Шатов безмерно благодарен Кириллову.

Для него счастье просто находиться подле жены, помогать ей, робко ухаживать...

Да, и Шатова Достоевский взял из сердца. С каким упоением, бережно, как бы лаская малейший оттенок чувств будущего отца (а Шатов ощущал себя именно отцом), описывает Достоевский сцену рождения человека. Может быть, в это время он вспоминал свое состояние, когда появилась на свет его незабвенная Соня?

...В руках у Арины Прохоровны копошилось крошечными ручками и ножками маленькое, красное, сморщенное существо, беспомощное до ужаса... Но кричавшее и заявлявшее о себе, как будто тоже имело самое полное право на жизнь...

- Какой хорошенький... - слабо прошептала Мари с улыбкой (до этого она желала, чтоб этот ребенок умер. - P. M.).

- Веселитесь, Арина Прохоровна... Это великая радость... с идиотски блаженным видом пролепетал Шатов, просиявший после двух слов Мари о ребенке... (X, 451-452).

Люди Достоевского все время беспокоятся друг за друга. Им надо, чтобы другой был выше, совершеннее, где-то в глубине души Шатов боялся, что Мари так и не примет ребенка. Ведь для человека Достоевского нет понятия своего и чужого. Сердце Шатова открыто для ставрогинского ребенка, может быть, больше, чем для собственного.

Великая любовь Шатова растопила мрак и отчаяние Мари.

Для Шатова и Мари все как будто переродилось. Мари вдруг обратилась в какую-то дурочку и все смотрела на Шатова и улы- 
балась ему, как блаженная. Шатов то плакал, как маленький мальчик, то говорил бог знает что, дико, чадно вдохновенно, целовал у нее руки... Он говорил ей о Кириллове, о том, как теперь они жить начнут «вновь и навсегда», о существовании Бога, о том, что все хороши... В восторге опять вынули ребеночка посмотреть (X, 453).

Посмотреть, чтобы еще раз убедиться в своем счастье, чтобы еще больше упиться восторгом. Чувствуется, как билось сердце Достоевского, когда он писал все это.

Наверное, они бы не были вдвоем так счастливы без этого третьего.

Значит ли это, что настоящая любовь может быть только в семье?

А затем «богатый пир»: белый хлеб, бульон и котлеты для «Марьи Игнатьевны», все прислано Кириловым, с поздравлением от старухи, нанятой им же.

В сущности, они одни на земле, без связей, без средств к существованию, но им не страшно: они счастливы.

У апостола Павла есть вдохновенное определение любви, широко известное:

Любовь долготерпит, милосердствует, любовь не завидует, не превозносится, не гордится, не бесчинствует, не ищет своего, не раздражается, не мыслит зла... все покрывает, всему верит, всего надеется, все переносит (1Кор. 13:4-5, 7).

Именно такова любовь Шатова, и это на фоне кошмарного беснования, охватившего русское общество. Воспользовавшись тем, что от счастья Шатов потерял бдительность, кровавый бес Верховенский заманил его в ловушку. И тут же погибла вся семья. Но эти двадцать страниц такого захватывающего счастья как-то не оставляют читателя.

\section{Примечания}

1 Здесь и далее цитаты приводятся по: Достоевский Ф. М. Полн. собр. соч.: В 30 т. Л.: Наука, 1972-1990. Номер тома и страницы указывается в круглых скобках после цитаты.

2 Шмеман А., прот. Дневники. 1973-1983 М.: Русский путь, 2005. С. 246, 167. Ср.: «...Чудовищный эгоцентризм, занятость собою, т. е. 
предельное выражение и плод яйности»; «...Вечное, немедленное, моментальное выскакивание маленького "я"...».

\section{Список литературы}

1. Аристотель. Никомахова этика. М.: Эксмо-пресс, 1997. 255 с.

2. Бахтин М. М. Проблемы поэтики Достоевского. 3-е изд.. М.: Худож. лит., 1972. 470 с.

3. Мочульский К. В. Достоевский: Жизнь и творчество. Paris: YMCAPress, 1980. 563 c.

4. Померани Г. Страстная односторонность и бесстрастие духа. М.-СПб.: Университетская книга, 1998. 618 с.

5. Ухтомский А. А. Лицо другого человека. М.: Изд-во Ивана Лимбаха, 2008. 664 c.

6. Антоний (Храповицикй), митр. Словарь к творениям Достоевского // Достоевский и православие: Публицист. сб. / Междунар. фонд единства православных народов. М.: Издат. дом «К единству!», 2003. С. 5-137.

Rita Osipovna Mazel Russian language and literature teacher, Lyceum no. 1501 of Moscow (Moscow, Russian Federation) levinanadya@mail.ru.

\section{SCENES OF HAPPINESS IN THE NOVELS OF DOSTOEVSKY}

Abstract: This article presents Dostoevsky to readers as an author praising happiness and felicity. Having lived through deep sorrows he acquired insight into another dimension of life. Like a longing pathfinder he states the unfeigned grace of life. "Life is a gift, life is mercy, and any minute may be the age of happiness", - this is the essence of his great novels.

People are not lonesome on Earth; they are bound by invisible threads. A loner may not succeed. One heart or one consciousness attracts another one like a magnet, as if claiming: thou art... Christ, with his Love and his Sacrifice, is the greatest miracle on Earth. It is impossible to be aware of Christ's existence and not to be joyful.

Dostoevsky reveals one of the main principles of life: when you love someone and sacrifice yourself to this person, you satisfy your aspiration for a beau ideal and feel like in heavens.

In this article the author analyzes selected scenes of happiness in Dostoevsky's novels: Arkady and his sister Liza's admiration for the sacrifice of their father Versilov; Alyosha and Grushenka, saving each other instead of 
committing sins and transgressing moral standards; Alyosha's dream about the Christ's first miracle in Cana of Galilee; Stavrogin's dream of the Golden Age of the blessed mankind... In Dostoevsky's tragic novel The Possessed (The Devils, or Demons) a reader faces an image of love - mutual, sacrificial, fulfilling, and blithe. There is probably nothing similar in the history of the world literature.

One can eminently feel the interconnectedness of Dostoevsky's heroes with another, higher world that penetrates into every aspect of their lives. All of his creatures are illumed by the light of other worlds. It is clear that there cannot be darkness, despair or hopelessness in Dostoevsky's work because even in the hell full of demons there is a place for righteous people, luminous (as Nikolai Berdyaev called them) and capable of love and personal sacrifice that means that the light is still shining in the darkness, and the evil darkness did not envelop it.

Keywords: Dostoevsky, joy, happiness, Christ, scenes, novel poetics

\section{References}

1. Aristotel'. Nikomakhova etika [Nicomachean Ethics]. Moscow, Eksmopress Publ., 1997. 255 p.

2. Bakhtin M. M. Problemy poetiki Dostoevskogo [Problems of Dostoyevsky's Poetics]. Ed. 3. Moscow, Khudozhestvennaya literatura Publ., 1972. 470 p.

3. Mochulskiy K. V. Dostoevsky: Zhizn i tvorchestvo [Dostoyevsky: Life and Work]. Paris, YMCA-Press Publ., 1980. 563 p.

4. Pomerants G. Strastnaya odnostoronnost' $i$ besstrastie dukha [Good One-sidedness and the Spirit of Dispassion]. Moscow, St. Petersburg, Universitetskaya kniga Publ., 1998. 618 p.

5. Ukhtomskiy A. A. Litso drugogo cheloveka [The Face of Another Person]. Moscow, Ivan Limbakh's Publ., 2008. 664 p.

6. Khrapovitskiy A., metropolitan. Slovar' k tvoreniyam Dostoevskogo [Dictionary of Dostoyevsky's Works]. Dostoevskiy $i$ pravoslavie [Dostoyevsky and Orthodoxy]. Moscow, Publishing house "K edinstvu" 2003, pp. 5-137. 